December 2011

\title{
Revisiting a Founding Assumption of Genocide Studies
}

A Dirk Moses

Follow this and additional works at: https://digitalcommons.usf.edu/gsp

\section{Recommended Citation}

Moses, A Dirk (2011) "Revisiting a Founding Assumption of Genocide Studies," Genocide Studies and Prevention: An International Journal: Vol. 6: Iss. 3: Article 10.

Available at: https://digitalcommons.usf.edu/gsp/vol6/iss3/10

This Articles is brought to you for free and open access by the Open Access Journals at Digital Commons @ University of South Florida. It has been accepted for inclusion in Genocide Studies and Prevention: An International Journal by an authorized editor of Digital Commons @ University of South Florida. For more information, please contact digitalcommons@usf.edu. 


\title{
Revisiting a Founding Assumption of Genocide Studies
}

\author{
A. Dirk Moses \\ European University Institute, Florence / University of Sydney
}

\begin{abstract}
Genocide studies has come a long way over the past decade, having attained a level of intellectual sobriety, academic credibility, and public recognition virtually inconceivable forty years ago. At the same time, there have been signs of convergence between the fields of genocide studies and Holocaust historiography and studies. This development can be challenging for those in Holocaust studies and historiography because the relationship betweem the two disciplines is complicated by genocide studies' claim to incorporate the Holocaust into its object of inquiry, whereas the reverse does not hold. There is a potentially subordinate situation here, or at least it can be experienced that way, even though Holocaust studies and historiography is a field with a substantial center of gravity, evidenced by the journals, book series, and research institutes devoted to the subject, such that it hardly needs to gesture to the relatively younger and smaller sibling, genocide studies. This article analyzes a recent critique of this convergence by revisiting the founding assumptions of Holocaust studies and genocide studies.
\end{abstract}

Key words: genocide, Holocaust, uniqueness, comparison, Lemkin

\section{Introduction}

Genocide studies has come a long way over the past decade, having attained a level of intellectual sobriety, academic credibility, and public recognition virtually inconceivable forty years ago. Universities around the world feature it in their curricula and host genocide studies centers. ${ }^{1}$ Whereas the initial monographs, anthologies, and encyclopedias on the subject were published mainly by minor houses, now any publication bearing the title Genocide is eagerly sought by the leading university presses. Two new and large anthologies-The Oxford Handbook on Genocide Studies and The Historiography of Genocide - take stock of the field, while three English language journals and an online encyclopaedia now serve to inform the scholarly community of the latest research advances. ${ }^{2}$ These developments were accompanied by a new interest in genocide in colonial and imperial contexts and the recovery of Raphael Lemkin's original, broader definition of genocide.

At the same time, there were signs of convergence between the fields of genocide studies and Holocaust historiography and studies. One example is the work of Donald Bloxham, the author of important monographs on the Nuremberg Trials, the Armenian genocide, and the Holocaust. All too rare were scholars like Bloxham and Jürgen Zimmerer who, on the basis of archival research, can operate as experts in both fields that seemed to have developed along parallel and rarely intersecting trajectories over the past twenty or thirty years. Here are signs of maturation, when those working in one field peer over the edge of the plate to see and learn how others are asking and answering questions posed of their particular case studies.

A. Dirk Moses, "Revisiting a Founding Assumption of Genocide Studies." Genocide Studies and Prevention 6, 3 (December 2011): 287-300. (C) 2011 Genocide Studies and Prevention. doi:10.3138/gsp.6.3.287 
This development may not be welcomed by those in Holocaust studies and historiography, because their relationship to genocide studies is complicated by its claim to incorporate the Holocaust into its object of inquiry, whereas the reverse does not hold. There is a potentially subordinate situation here, or at least it can be experienced that way, even though Holocaust studies and historiography is a field with a substantial center of gravity, evidenced by the journals, book series, and research institutes devoted to the subject, such that it hardly needs to gesture to the relatively younger and smaller sibling, genocide studies.

Unfortunately, though, this means that colleagues in Holocaust fields may not feel like they are being addressed by a call for papers for a genocide studies conference. Given that we are all interested in similar questions and, I presume, motivated by similar moral imperatives, the continuing cleavage between the fields is regrettable.

The most recent expression of resistance to the direction of genocide studies is the Israeli-American historian Omer Bartov's 2010 keynote lecture and publication. Delivered at academic meetings in the Great Britain and the United States, his paper criticized some of these developments in genocide studies. In particular, Bartov criticized Donald Bloxham's The Final Solution: A Genocide, my anthology, Empire, Colony, Genocide, and, briefly, Mark Mazower's monumental Hitler's Empire. A number of issues vexed him: (1) the proposition that discourse about the Holocaust screens out attention to other genocides, (2) the shift in focus to colonialism (or empire) in genocide studies, which he fears subsumes the Holocaust into the logics of an imperial role at the cost of anti-Semitism's central dramatic role, and (3) Holocaust and genocide history that omits or marginalizes victims' perspectives and experiences. All these concerns were linked with palpable alarm about the implications for Israel, although the country features marginally at most in these books. Be that as it may, Bartov was signaling disquiet with the direction of genocide studies: there is "no room in the broad sketches of comparative genocide studies and the generalized overview of events," he lamented, for "the uniqueness of [victims'] experiences as individuals, as members of communities, of groups, of nations." 3

As it is impossible to address all of Bartov's contentions herein, I will address his points (1) and (2) as a way of revisiting two founding assumptions of our field that were articulated by Leo Kuper in his justly famous 1981 book, Genocide: Its Political Use in the Twentieth Century. ${ }^{4}$ I do so because Bartov resorts to Kuper to buttress his contention that the centrality of Holocaust memory makes, rather than reduces, space for other genocides, and to advance his case against the colonial (actually imperial) frame for genocide studies. I proceed by assessing each point in turn. It will become apparent that Bartov is trying to update the Holocaust-uniqueness claims of previous decades that genocide studies has left behind for pluralist research agendas. In this way, his project is regressive as well as empirically unsustainable.

\section{The Holocaust and Other Genocides}

The relationship between the two concepts, Holocaust and genocide, and between the two fields, Holocaust studies and genocide studies, is unstable, and necessarily so. Although "genocide" actually preceded "Holocaust" as the master concept of human destruction, Holocaust gradually supplanted genocide as the main signifier of evil, especially in North America. But because the Holocaust is also a genocide, it cannot totally dominate a discursive terrain that has to name and respond to contemporary atrocities; the Holocaust was in the past, but genocides are all too current. At the very least, the two concepts coexist in a complex-part enabling, part competitiverelationship. ${ }^{5}$ 
Bartov, by contrast, sees the relationship in simplistic, linear terms: "other genocides came into public and scholarly view thanks to the emergence of the Holocaust as a major historical event and not despite it"; and "the Holocaust was the event that crystallized the most complete definition of genocide and motivated its legal adoption." 6 He cites Kuper as an authority for these propositions for, as he quotes Kuper, it was "the devastation of peoples by the Nazis which provided the impetus for the formal recognition of genocide as a crime in international law."7

The slippage in Bartov's reliance on Kuper is immediately apparent: like Raphael Lemkin, Kuper wrote about "the devastation of peoples by the Nazis" in general, not only about the Jews. And that is how United Nations delegates regarded the matter, rejecting the Soviet attempt to link genocide intrinsically to fascism and Nazism, let alone the Jewish experience. The term "Holocaust," or a synonym for it, was not current at the time; as Bartov knows, consciousness of the centrality of the Jewish question was less apparent to contemporaries then than to historians now. In other words, "the Holocaust"- the genocide of the Jews-was not the stimulus for the UN Convention on the Prevention and Punishment of the Crime of Genocide (UNCG).

Kuper was certainly correct that the shock occasioned by "the devastation of peoples by the Nazis" spurred along deliberations for the UNCG, but on no reading of the evidence can the ensuing definition of genocide be said to be "the most complete." For as Bartov himself admits, the UN delegates ultimately omitted political groups as a victim category and cultural genocide as a crime, contrary to Lemkin's dogged advocacy of the latter concept. ${ }^{8}$ Genocide was limited to its physical and biological aspect. My reading of British diplomatic documents about the UN deliberations between 1946 and 1948 indicates that many contemporaries found the suggested cultural dimensions of genocide to be a distorting dilution of what they regarded as the real crime, mass murder. That was the transgression that the Nazis had committed. So, most contemporaries concluded, genocide must mean mass murder: that was what "shocked the conscience of mankind."9

The growth of Holocaust consciousness intensified the association between genocide and mass murder in the public mind and is probably the inspiration of the "special intent" (dolus specialis) provision in genocide jurisprudence, although that stipulation is barely mentioned in the travaux préparatoires (preparatory work) of the UNCG, thereby making it extremely difficult to prove the crime. ${ }^{10}$ Bartov himself writes that "the Holocaust [is used] as a template against which other genocides can be measured and assessed,"11 echoing Barbara Harff's earlier observation that "The Jewish Holocaust ... is employed as the yardstick, the ultimate criterion for assessing the scope, methods, targets, and victims of [other] genocides." 12 This is where Bartov's desire to have his cake and eat it too comes unstuck, for it is illogical to suppose that the Holocaust is singular, unprecedented, special, and so forth, on the one hand, and maintain that its use as template or yardstick does not occlude other genocides, on the other. Based on this logic, a genocide must resemble the Holocaust to become visible. But what of mass violence that does not resemble it? ${ }^{13}$

Many genocide scholars and political leaders continue to define genocide as a crime of the state entailing mass killing motivated by racist ideology, even though neither Raphael Lemkin nor the UN definition limited genocide in this way. ${ }^{14}$ Thus, when the president of Turkey brushed off criticisms of his meeting with Sudan's leader with the statement that Muslims do not commit genocide, he was saying that genocide is a non-political hate crime committed against hapless civilians that has nothing to do with the legitimate right of a state to suppress a violent rebellion. The UN's 2005 Report of the International Commission of Inquiry on Darfur effec- 
tively agreed with him in determining the absence of genocide by the Sudanese state in Darfur. ${ }^{15}$ If mass violence does not resemble the Holocaust in being a massive racial hate crime, it is screened out as non-genocidal.

To understand how and why the Holocaust became the template and yardstick, we need to dig beyond the usual clichés. The sociologist Jeffrey C. Alexander has explained how the Holocaust became "cultural trauma" of universal appeal through a complex process of symbolic transference and inversion. ${ }^{16}$ "The Holocaust" did not exist as a discursive category when the concentration camps were liberated. Western, largely Christian, publics were appalled by Nazi crimes, but regarded them simply as a very large atrocity and identified with the Allied soldiers rather than the liberated Jewish survivor inmates. Nazism, not the Holocaust, was the symbol of evil, and its polluting presence was to be expunged by the worldwide victory of liberal democracy. In this way, Nazi crimes were narrated into a progressive philosophy of history and left behind.

The inner logic of symbolic association, however, undermined this smug narrative, Alexander continues. For if Jews had been Hitler's primary target, as became clear in the post-war period, then they must be of a piece with liberal democracy, and therefore the task is to expunge anti-Semitism and racism from Western societies. Moreover, by deriving abstract moral criteria from the Second World War experience, the ethical foundation of the West could be held up to scrutiny by domestic critics. And in doing so, elements of Nazism could be found there by analogy, a process that Alexander calls "symbolic extension" - that is, identifying apparent analogies between Nazism and situations, circumstances, and policies that obtained in one's own polity. Simultaneously, with the acculturation of the Jewish community and the popularization of "accessible" Jewish Holocaust victims like Anne Frank, psychological identification with Jewish victims became possible for non-Jews. Consequently, what enabled the Jewish experience to be singled out from that of other victims of Nazism (and other demographic calamities, such as the policies of Stalin and Mao) and invested with "extraordinary gravitas," so that it became considered a "radical evil" and a unique "world historical" event, is that it can function as a "trauma drama" for everyone. The drama of Jewish victimization was de-historicized and became an emblem for the disastrous consequences of racism and intolerance generally. Henceforth, the Holocaust was a proper, not a common noun-the "archetypal sacred-evil of our time." 17 The progressive narrative was supplanted by a tragic one of innocent victims and damaged survivors, the memory of whose fate must be kept alive to prevent such suffering from recurring.

The insistence on the Holocaust's uniqueness brought with it an inescapable dilemma, Alexander observes. For it to be sacred, the Holocaust needed to be protected from profanation by contamination with "normal" evil although, as the ultimate standard of evaluation, it would inevitably be associated with other events. There was no avoiding symbolic extension, then, and those who were thereby associated with its evil are automatically polluted and needed to undergo ritual cleansing: "One must do justice and be righteous," notes Alexander. "This performative purification is achieved by returning to the past, entering symbolically into the tragedy, and developing a new relation to the archetypal characters and crimes." 18 The Holocaust was universalized in this way.

Since his first influential article on the subject in 2002, Alexander has produced a book-Remembering the Holocaust: A Debate (2009)_in which he restates his argument, allows his critics to respond, and then concludes with a rejoinder. ${ }^{19}$ Now, he is less convinced that Holocaust memory is so salutatory after all. Particularistic 
uses of the Holocaust violate "the universalizing moral principles that the memory of the Holocaust calls upon all of us to sustain." 20 Alexander's belated recognitionothers have been making such points for some time-is resisted by Bartov, who cleaves to a heroic narrative of Holocaust memory by attempting to discredit, without refuting, those who complicate this simplistic morality tale. ${ }^{21}$

Instead of keeping up with the debate, Bartov recurs to Kuper's point that the UN's criminalization of genocide was the product of a "western liberal worldview" (Bartov) that, according to Kuper, finds "that massive slaughter of members of one's own species is repugnant to man." 22 It is questionable whether Bartov's conscription of Kuper into such a Western-centric perspective is plausible; after all, arrogating morality to the West was hardly thinkable for someone who devoted his career to the struggle against apartheid. ${ }^{23}$ And the point that consciousness of genocide is a particularly Western virtue needs to be related to the UNCG's blindspots-namely the excision of cultural genocide-and genocide's later equation with mass murder and the Holocaust. Far from being the moral breakthrough that Bartov contends, the genocide and human rights regimes that developed after the Second World War offered minorities less rather than more protection than they enjoyed, at least legally, under the League of Nations. The UNCG and the Declaration on Human Rights could be passed by the great powers and a small number of member states at the time because they did not entail mechanisms to interfere with state rights, as Kuper, never naïve, understood. ${ }^{24} \mathrm{~A}$ founding assumption of our field, then, that the Holocaust opens rather than closes vistas, needs to be revisited.

\section{The Causes of Genocide}

Bartov similarly conscripts Kuper for his assault on the colonial orientation in some recent genocide scholarship, because Kuper, he notes, criticized Jean-Paul Sartre's wholesale equation between genocide and colonialism. Recent scholarship of the "colonial turn" has also distanced itself from Sartre's simplification, but Bartov has not read much of it, preferring to reduce the debates of the 2000s to those of the early 1970 s, to which Kuper was responding. The slippage is apparent when Bartov summarizes our positions, accurately, as contending "that the Holocaust itself was largely part of a greater German and European colonial undertaking and logic from which it cannot be isolated," ${ }^{5}$ which is not the same thing as casting Israel as a settler colonial purveyor of genocide or reducing the Holocaust to a mere case of colonial genocide, the intellectual and political crimes that he insinuates some of us have committed. ${ }^{26}$

Kuper was alive to ambiguity and complexity, by contrast, and Bartov finds himself forced to adduce quotations attesting to the prevalence of genocide in Western colonial history. ${ }^{27}$ What he does not ask is why, besides the work of few scholars who were brushed aside as provocateurs and outsiders, there was virtually no research on this topic until a new generation of scholars, mainly outside North America, began to ask hard questions in the later $1990 \mathrm{~s}$ and $2000 \mathrm{~s}$ about genocide in their countries or their former colonies. ${ }^{28}$ Here were cases that did not resemble the Holocaust, and that is one reason why they were ignored, and often still are. When claims are advanced attesting to genocide in settler colonialism, they are met with the answer that they could not be genocide because genocide must resemble the Holocaust or the attributes of genocide that are copied from the Holocaust, genocide's "template." 29

Happily, the consensus has changed, and now research on colonial genocide is legitimate in our field, as evidenced by the excellent special issue on the subject in this journal. ${ }^{30}$ This development suggests that Bartov's intervention represents a 
backlash against the pluralization of research questions by attempting to return to the Holocaust-uniqueness assumptions prevalent between the 1970s and 1990s, albeit in a more genteel version. He thereby wants to revive a problematic foundational assumption of the field that would discount the recent progress made in understanding the causes and consequences of colonialism and indigenous genocides. As noted above, Bartov draws on Kuper in his case against the colonial orientation in genocide studies. Kuper (1908-1994), we know, was a Lithuanian-born Jewish South African lawyer and sociologist and expert on racism and decolonization, so it is no surprise that his work displays profound knowledge of postcolonial affairs. ${ }^{31}$ His emphasis on ethnic cleavages in postcolonial societies, which he regarded as the root cause of most genocides, led to a peculiar distinction, namely between genocides as "a phenomenon of the plural or divided society, in which division persists between peoples of different race or ethnic group or religion, who have been brought together in the same political unit" and those produced by what he calls "totalitarian political ideologies, of absolute commitment to the remaking of society in conformity with radical specifications, and a rooting out of dissent." 32 Kuper was distinguishing postcolonial conflict, like the Biafran Civil War in Nigeria in the second half of the 1960s, from the Holocaust.

The salient distinction is "between situations in which there is some threat, however slight, to the interests of those who perpetrate or plan or incite massacres, and situations devoid of such threat." He insisted, further, that "one can distinguish between massacres of a weak defenseless hostage group used as a scapegoat, and massacres arising in the course of a conflict in which there is some realistic threat or challenge to the interests of the dominant group in the host society." 33 In the latter, then, political considerations are salient, but not in the former, which are purely ideological, and the Holocaust is the most striking example of it.

This distinction was at once constitutive of Holocaust studies and genocide studies. To underline my point, let us recall some examples of how genocide has been defined. According to Israel Charny, genocide is "the mass killing of substantial numbers of human beings, when not in the course of military action against the military forces of an avowed enemy, under conditions of the essential and defenselessness and helplessness of the victims." 34 More recently, Jacques Semelin was telling the same story when he distinguished between destruction for subjugation, which is political and partial, and genocide for total eradication, like the Holocaust, which is driven by the delusional, paranoid, and non-political considerations of ethnic purity and aesthetics. ${ }^{35}$

What these scholars are suggesting is a hierarchy between types of human destruction. The latter type is worse because it targets innocent victims of paranoid and ultimately inexplicable racial hysteria, while the former type of destruction is an explicable outcome of interethnic conflict, often in civil war, in which the victims are not passive and therefore not completely innocent. (Below, I elaborate on why this construction of "the victims" is untenable.)

To summarize, whereas most mass violence is the byproduct of ethnic/national conflict over "real" issues like land, resources, and political power, no such conflict is discernible in the Holocaust of European Jewry, whose victims were passive and agentless objects of the perpetrators' "hallucinatory" ideology. ${ }^{36}$ This ideology sets the Holocaust apart in another way: Because it posited a global Jewish conspiracy, all Jews, irrespective of their proximity to Nazi-controlled territory, were fated to die for the sake of redeeming Germany and European civilization, whereas victims of prosaic genocides were confined to the spatial and temporal extent of actual conflict over pragmatic questions. The Holocaust-and by inference, genocide-was 
ideologically driven, limitless, and total; “normal” mass violence is politically explicable, limited, and partial. In this way, the Holocaust was a massive hate crime in which agentless, innocent victims were killed purely for who they are and not for anything they had done. They were placed beyond the "universe of obligation," to use Helen Fein's term. ${ }^{37}$ This is what Norman Cohn meant when he wrote, "The Jews were hunted down with a fanatical hatred which was reserved for them alone," although they "did not constitute a belligerent nation, or even a clearly defined ethnic group, but lived scattered across Europe from the English Channel to the Volga, with very little in common to them all save their descent from adherents of the Jewish religion." 38 To explain this, he continued,

I began to suspect that the deadliest form of anti-Semitism, the kind that results in massacre and attempted genocide, has little to do with real conflicts of interest between living people, or even with racial prejudices as such. What I kept coming across was ... a conviction that Jews-all Jews everywhere in the world-form a conspiratorial body set on ruining and then dominating the rest of mankind. ${ }^{39}$

Kuper's distinction between racial, ideological, and non-political genocides, on the one hand, and partially political genocides, on the one other, conceals a number of problems that have been highlighted by Martin Shaw in his work on war and genocide. ${ }^{40}$ What Kuper, Bartov, and so many others are eliding is the combatant/civilian distinction within such groups. They are ignoring the fact that both categories of genocide contain massacres of civilians who pose no objective threat to perpetrators in actual conflicts. After all, what kind of agency can we ascribe to such victims, like the women and children who were marched into the Mesopotamian desert by Ottoman authorities in April 1915?

Now Kuper and others might respond by conceding this point but insisting that the distinction between European Jews and, say, Ottoman Armenians was that members of the latter group were engaged in a nationalist armed rebellion in wartime while Jews were not belligerents in the same sense or, indeed, in any sense. How does one answer this commonly made argument in the field? The answer that I provide is necessarily inadequate because of space constraints but the basic points will be apparent ${ }^{41}$ :

1. We need to replace this stark dichotomy of ideology and paranoia on the one hand and political rationality on the other with a spectrum that recognizes that ideology and paranoia are present in all genocides.

2. The current distinction fails to recognize how prejudice against groups is generated and works, and how paranoia is present in this process, and it fails to understand that the construction of "enemy peoples" who must be destroyed is not uncommon in world history.

3. Security imperatives and fear, rather than race hatred, are the operative logics of genocide. Far from being a massive hate crime, as commonly supposed, genocide is an extreme form of counterinsurgency or security measure, marked above all by pre-emption and collective punishment as well as the destruction of groups suspected of insurgency and collaboration with enemy forces. It is therefore governed by political logics, rather than solely by racial logics.

All too often, a minority group is held collectively guilty and is collectively punished for the actions of some of its members. The group as a whole is seen as a security risk-a potential fifth column-and so it can be interned, deported, or otherwise 
destroyed in toto for reasons of state. Consider why virtually all Armenians and other Ottoman Christians were condemned as collectively guilty for the actions of a tiny minority of nationalists? Just as "the Jews" had not betrayed Germany or Hungary at the end of the First World War, neither had "the Armenians" betrayed the Ottoman Empire in 1915 although a number of Jews and Armenians had participated in subversive activity. On the whole, these communities were loyal. What this dynamic tells us about the distinction with which we began-between genocides based on real and hallucinatory conflict-is that genocides generally are driven by traumatic memories of past events in which, for various reasons, a group is construed as disloyal and held collectively guilty and then collectively punished, deported, or destroyed pre-emptively to prevent the feared repetition of the previous traumatic experience. Kuper's tidy distinction, inspired by the social-scientific tendency to categorize phenomena rather than account for complex processes, ignores the difference between the loyal and disloyal within such groups-the victims to whom Bartov thinks we should attend-for signs of exterminatory ideology by potential perpetrators. ${ }^{42}$

Accordingly, it is largely fruitless to search for "real" interactions between victim and perpetrator as many Turkish historians do when claiming the Ottoman state was provoked by Armenian nationalists. The element of pre-emption means that groups are attacked before its members can subvert the state. Moreover, pre-emption is based on a temporal slippage, that is, on particular memories of past interactions, however unreasonably interpreted, which essentially entails attacking groups because of what some or many of its members might do. Genocide, I repeat, is governed more by fantastical security imperatives than by the aesthetic of racial purity. Paranoid threat assessments leading to pre-emptive strikes against collectives are present in genocides generally. To that extent, all genocides can be placed on this spectrum with the Holocaust rather than be separated into a distinct category. Kuper's distinction, a foundation of our field, should be revisited.

\section{The Field of Genocide Studies}

Where did these assumptions of our field come from? We need to briefly consider its founders' biographies and the intellectual and cultural context of the 1970s. Predominantly of Jewish and Armenian backgrounds, they understandably thematized the genocidal victimization of their own families as a motivation for their endeavors. ${ }^{43}$ Some, like Robert Melson, a child survivor of the Holocaust, first worked in postcolonial area studies-Nigerian labor movements, in his case-while the Holocaust, for him, loomed in the background. He comments, "As did so many of my generation growing up in the late 1950s and 1960s, I had hoped that Africa, the Third World, would avoid the recent horrors of Europe." The genocidal massacres and famine of the Ibo people in Nigeria in the late 1960s spurred his interest in genocide generally: "From then on I knew I had to return to the Holocaust to try to make sense of it both at the level of personal emotion and in some broader comparative intellectual perspective." 44 What is more, the Holocaust functioned as a traumatic memory, making contemporary events that were felt to resemble what the Jews suffered under the Nazis literally unbearable. Thus, Melson writes of his shock at hearing about the Ibo massacres, "I felt as if the twenty-some years after the Second World War had been compressed into a few minutes. The Holocaust monster was on the prowl again, and it was no use trying to escape its implications in Africa or elsewhere." 45 Europe's traumatic past had led to a commitment to postcolonial reconstruction and then back to the Holocaust and comparative genocide after the genocidal failure of that optimism in these new nation-states. Others like Helen Fein moved 
to genocide studies after writing about the Holocaust, though, like Melson, she had previous interest in imperial history. ${ }^{46}$ Jack Nusan Porter came to it from his work on Jewish radicalism. ${ }^{47}$ Irving Horowitz was also rooted in the Jewish left and, like Porter, combined his growing attachment to Israel, as a survivor community, over the years with a broad concern for political violence and the persecution of minorities and small nations. ${ }^{48}$ It is apparent that, for many, the genocide concept expressed the moral impulse to universalize the lessons of the Holocaust in light of post-war history. Israel Charny spoke from the heart when he stated that he was

committed to the ideal that understanding the processes which brought about the unbearable evil of the Holocaust be joined with the age-old Jewish tradition of contributing to the greater ethical development of human civilization, and that a unique memorial to the Holocaust be forged in the development of new concepts of prevention of genocide to all peoples. ${ }^{49}$

Perhaps it is the case, as Daniel J. Goldhagen observed recently, that "because of the Holocaust, Jews are more prone to identifying with the victims of genocide. Their empathy thus roused, they can more easily mobilize their emotions, including outrage, behind the acknowledgment of seemingly dry and abstract moral principles."50 The founders' humanistic generosity of this spirit can be best appreciated against the background of the debate in the 1970s in which some claimed that the terms Holocaust and genocide referred only to the Nazi destruction of Jews and could not be "shared" with others. ${ }^{51}$ To their immense credit, genocide scholars (as they styled themselves) always opposed the proposition that the Holocaust was the only genocide in human history, though many seem to have regarded it as the most extreme, and even unique, genocide. ${ }^{52}$ For that reason, they often founded institutes for Holocaust and genocide studies rather than solely for genocide studies.

For these reasons, an important conclusion that Melson-and the emerging field generally-reached was that the Holocaust differed signaly from the Biafran case because there was no intention to murder every last Ibo. They were permitted, indeed encouraged, to reintegrate into Nigeria after the end of the civil war in 1970. This did not really look like genocide because it did not resemble the Holocaust: "The Nigerians were not Nazis, and the Ibos were not Jews."53 Analogously, as Kuper posited, it was necessary to distinguish between violent attacks on innocent civilians on racial grounds that resembled the Holocaust, on the one hand, and civil war on the other. These are the problematic identifications I am talking about: For a genocide to occur, the perpetrators must resemble Nazis and the victims must resemble Jews. And it is such conflations that I think the field should cease making because they insert a distorting lens into our understanding of what is transpiring in any particular violent conjuncture. ${ }^{54}$

\section{Lemkin's Approach}

A number of scholars have been inspired by Raphael Lemkin's unpublished world history of genocide, about which I am writing in my forthcoming book, Genocide and the Terror of History. He approached the Holocaust as he would any history and any genocide; he seems not to have invested the Holocaust with any metahistorical significance despite his own close brush with the Nazis and his family's murder. Taking the perspective of the longue durée naturally told against such investment. He observed patterns of immanence rather than transcendence, the quotidian rise and fall of nations and empires rather than moments of world historical significance. His own assumption was that the norm of diversity resisted the imposition of homogeneity. Note how he included the Nazi regime in this list of homogenizing empires: 
At different stages of history some cultures have been stronger, some have been weaker, but the diversity of cultures in the world has been aspired to from earliest times. And once a tendency was felt to impose one culture upon the rest of the world, like in the case of Greece, Rome, Assyria, France (under Louis XVI), Nazi Germany under Hitler, this tendency was always broken up by counter-forces which ultimately secure the principle of diversity. ${ }^{55}$

He saw his own efforts as one of these counter-forces. He was no cultural relativist, firmly believing that the West, as the origin of humanitarian international law, was the motor of civilizational development. It drove the transition from the barbarism of total warfare and wars of extermination of antiquity and the Middle Ages to the modern laws of war and occupation with their distinction between civilians and combatants. If this view, shared by other liberal Jews of his generation like Norbert Elias, has been challenged by critics who associate genocide and the Holocaust with modernity, Lemkin's nascent theory of cultural learning processes is worth recalling. The memory of genocide spurs the effort to prevent it, perhaps a secular manifestation of the Jewish notion that "the secret of redemption is memory."

Lemkin did not want to limit that memory to the Holocaust or place genocides in a hierarchy. That is why he coined the term genocide as a "generic" notion. 56 While the genocide of Jews (including 49 members of his family) was understandably an unbearable trauma for him, he was an unusually sensitive person whose conscience was shocked by genocide in world history well before the Holocaust. It is undoubtedly true, as Bartov writes, that many Europeans were existentially shaken by the Nazi camps and, like Theodor W. Adorno and others, regarded the Holocaust as an event of world historical significance that transformed European culture. No one denies that. What Bloxham, Mazower, and I are saying-and we are hardly original here-is that it is significant that it took the Nazi treatment of Europeans as colonial subalterns to shock Europeans. When the United Nations prefaced its post-war declarations with statements about events that "shock the conscience of mankind," we need to ask who defined that conscience and which events were excluded. Why had Europeans not been more shocked by their own colonial violence? If Bartov is not surprised by the implied racism in this selective shock-a selectivity noted critically by non-European intellectuals like Aimé Césaire-then surely it is important to subject this construction to scrutiny rather than celebrate its alleged universality. ${ }^{57}$ Inspired by Césaire's insight, Mark Mazower has shown that many Europeans were prepared to participate in the Nazi anti-Bolshevik reconfiguration of the continent and were only pushed into noncooperation or resistance by the Nazis' policies of plunder, which he suggests were experienced as colonial; in other words, Europeans were only shocked by Nazism when it treated them-including Jews-as colonial subjects to be exploited, enslaved, and murdered at the occupier's whim. This experience and later memory was screened out by depicting the Nazi genocide of Jews as a massive hate crime divorced from the paranoid security imperatives of German authorities trying to win an imperial war of conquest and occupation. Far from providing insight, as Bartov thinks, it promoted blindness to genocidal episodes around the world because they did not resemble the Holocaust.

\section{Conclusion}

It is not that insightful reservations or objections to large-scale and broad-range comparison and contextualization have not been made. They have. As A.G. Hopkins noted, 
Historical comparisons that detach states or societies from their chronological location enable similarities and differences between particular features, such as military resources and ideology, to be closely observed. But they also run the risk of minimizing or even overlooking important shifts in the global context within which the comparison is set. 58

For that reason, he argues, definitional specificity is imperative.

Very broad definitions support broad conclusions and allow comparisons to be drawn from a wide variety of regions and eras. Their spaciousness is attractive, but their value is limited because conclusions drawn at a very high level of generality are unlikely to be illuminating. Poorly specified definitions, and the comparisons that accompany them, may also produce dubious results. ${ }^{59}$

What he says about comparing empires obtains equally when comparing genocides:

Comparing like with like is a principle that can be applied more easily in distinguishing apples from pears than in categorizing empires. All empires must share some features if they are to retain the name, but what they share may be less significant than what separates them. ${ }^{60}$

These are sage warnings against overreaching or hasty generalizations based on insufficient research and reflection on the methodological rigor of comparing certain cases. They should be heeded by genocide scholars. These are not the objections made by Omer Bartov. To point to the presence of imperial logics in the Holocaust is not to suggest that it is "just like any other genocide in world history"-the dreaded and feared relativization of the Holocaust. It is to note, as Lemkin did, that genocides, for all their variation, share some recurring features that congeal in different constellations in different conjunctures. Far more, such an exercise is intrinsic to the program set forth by Lemkin, namely to advance immanent rather than metahistorical explanations for its occurrence. This is how the Holocaust can be made relevant to world historians who are more interested in themes like demography, migration, and state-formation. To be of genuine global interest, the Holocaust needs to be deprovincialized from its signification within an exclusively Jewish and Western narrative about the achievement of human rights and genocide prevention, the sentimental narrative expressed and enjoined by Bartov. That narrative is simply implausible for large sections of the global population, shows no genuine interest in world history, and is not in accordance with the evidence. Careful attention to the facts "dispels all pretentious rhetoric and forms a space for analysis unobstructed by ideological posturings." 61

\section{Acknowledgment}

Thanks to the editors for the invitation to publish this article and useful feedback on an earlier draft.

\section{Notes}

1. Some of these paragraphs draw on my "The Field of Genocide Studies," in Genocide: Critical Concepts in Historical Studies, ed. A. Dirk Moses, 6 vols. (Abingdon: Routledge, 2010), 1-23. Typically, these centers combine genocide with research on the Holocaust, human rights, or peace and conflict studies (e.g., The Center for the Study of Genocide and Human Rights at Rutgers University, http://cghr.newark.rutgers.edu/index.html [accessed 1 July 2011]) or they are dedicated to genocide prevention, like the Asia-Pacific Centre for the Responsibility to Protect at the University of Queensland, http://www.r2pasiapacific.org (accessed 1 July 2011). 
2. Donald Bloxham and A. Dirk Moses, eds., The Oxford Handbook of Genocide Studies (Oxford: Oxford University Press, 2010); Dan Stone, ed., The Historiography of Genocide (Houndmills: Palgrave MacMillan, 2008). A dictionary has also appeared: Samuel Totten and Paul R. Bartrop, eds., The Dictionary of Genocide, 2 vols. (Westport, CT: Greenwood Press, 2008). The relevant journals are the Journal of Genocide Research (since 1999) and Genocide Studies and Prevention (since 2006), though Holocaust and Genocide Studies (since 1986) does occasionally cover other genocides besides the Holocaust. There is a German journal, the Zeitschrift für Genozidforschung (since 1999) and the Argentine Revista de Estudios sobre Genocidio (since 2007), which shares articles with the two English-language journals. Then there is the new Online Encyclopedia on Mass Violence, www.massviolence.org (accessed 1 July 2011).

3. Omer Bartov, "Genocide and the Holocaust: What Are We Arguing About?" An abridged version was published as a sort of tribute to Leo Kuper in Gewalt und Gesellschaft: Klassiker modernen Denkens neu gelesen, ed. Uffa Jensen et al. (Göttingen: Wallstein, 2010), 381-93, 393; Donald Bloxham, The Final Solution: A Genocide (Oxford: Oxford University Press, 2009); A. Dirk Moses, ed., Empire, Colony, Genocide: Conquest, Occupation and Subaltern Resistance in World History (New York: Berghahn, 2008); Mark Mazower, Hitler's Empire: Nazi Rule in Occupied Europe (London: Penguin, 2008).

4. Leo Kuper, Genocide: Its Political Use in the Twentieth Century (New Haven: Yale University Press, 1981).

5. Cf. A. Dirk Moses, "The Holocaust and Genocide," in The Historiography of the Holocaust, ed. Dan Stone (Houndmills: Palgrave MacMillan, 2004), 533-55.

6. Bartov, "Genocide and the Holocaust," 383.

7. Kuper, Genocide, 20.

8. Bartov, "Genocide and the Holocaust," 390; A. Dirk Moses, "Raphael Lemkin, Culture, and the Concept of Genocide," in Bloxham and Moses, The Oxford Handbook on Genocide Studies, 19-41.

9. See, for example, British National Archives, F0 371/72692; FO 371/67573; FO 371/72693; HO 45/25308; CO 936/19/2; CO 936/19/4.

10. See, generally, the discussion in Katherine Goldsmith, "The Issue of Intent in the Genocide Convention and Its Effect on the Prevention and Punishment of the Crime of Genocide: Toward a Knowledge-Based Approach," Genocide Studies and Prevention 5, no. 3 (2010): 238-57; and Hannibal Travis, "On the Original Understanding of the Crime of Genocide," Genocide Studies and Prevention (forthcoming).

11. Bartov, "Genocide and the Holocaust," 388.

12. Barbara Harff, "No Lessons Learned from the Holocaust? Assessing Risks of Genocide and Political Mass Murder since 1955," American Political Science Review 97 (2003): 57-73.

13. A. Dirk Moses, "Genocide and the Terror of History," Parallax 17, no. 4 (2011): 90-108.

14. A. Dirk Moses, "Toward a Critical Theory of Genocide," Online Encyclopedia of Mass Violence, 18 April 2008, http://www.massviolence.org/Article?id_article=189.

15. Report of the International Commission of Inquiry on Darfur to the United Nations Secretary-General, Pursuant to Security Council Resolution 1546 of 18 September 2004, UN Doc. S/2005/60 (25 January 2005), 132, para 518.

16. Jeffrey C. Alexander, "On the Social Construction of Moral Universals: The 'Holocaust' From War Crime to Trauma Drama," European Journal of Social Theory 5, no. 1 (2002): $5-85$.

17. Ibid., 31 .

18. Ibid., 30-33; emphasis original.

19. Jeffrey C. Alexander, Remembering the Holocaust: A Debate (Oxford: Oxford University Press, 2009).

20. Jeffrey C. Alexander, "On the Global and Local Representations of the Holocaust Tragedy," in Alexander, Remembering the Holocaust, 179, 185. 
21. Bartov, "Genocide and the Holocaust," 392. Bartov's method of lumping together academic colleagues with Holocaust deniers as if they constitute a coherent and self-conscious group of hostile opponents mirrors that of Elhanan Yakira, the Schulman Professor of Philosophy of the Hebrew University in Jerusalem, in his book, Post-Zionism, Post-Holocaust: Three Essays on Denial, Forgetting, and the Delegitimation of Israel (New York: Cambridge University Press, 2010). See especially 329-30.

22. Kuper, Genocide, 84, quoted in Bartov, "Genocide and the Holocaust," 390.

23. Kuper, Genocide, 84.

24. Mark Mazower, No Enchanted Place: The End of Empire and Ideological Origins of the United Nations (Princeton: Princeton University Press, 2009); Sam Moyn, The Last Utopia: Human Rights in History (Cambridge: Harvard University Press, 2010); Leo Kuper, The Prevention of Genocide (New Haven: Yale University Press, 1985).

25. Bartov, "Genocide and the Holocaust," 382; emphasis added.

26. Tellingly, where Bartov makes such claims, he writes in the passive voice because he cannot find any evidence of them in the writings of Bloxham, Moses, or Mazower.

27. Bartov, "Genocide and the Holocaust," 389.

28. Russell Thornton, American Indian Holocaust and Survival (Norman: University of Oklahoma Press, 1987); Tony Barta, "Relations of Genocide: Land and Lives in the Colonization of Australia," in Genocide and the Modern Age, ed. Isidor Wallimann and Michael N. Dobkowski (Westport, CT: Greenwood Press, 1987), 237-52; M. Annette Jaimes, ed., The State of Native America (Boston: South End Press, 1992); Ward Churchill, A Little Matter of Genocide (San Francisco: City Lights, 1997); David E. Stannard, American Holocaust (New York: Oxford University Press, 1992).

29. See the discussion in A. Dirk Moses, "The Meaning of Genocide," Online Opinion, 18 March 2008, http://www.onlineopinion.com.au/view.asp?article=7253; and A. Dirk Moses, "Conceptual Blockages and Definitional Dilemmas in the Racial Century: Genocide of Indigenous Peoples and the Holocaust," Patterns of Prejudice 36, no. 4 (2002): 7-36.

30. Genocide Studies and Prevention 4, no. 1 (2009).

31. Leo Kuper, Passive Resistance in South Africa (London: Cape, 1956); Leo Kuper, An African Bourgeoisie (New Haven: Yale University Press, 1965); Leo Kuper, The Pity of it All: Polarization of Ethnic and Racial Relations (Minneapolis: University of Minnesota Press, 1977).

32. Kuper, Genocide, 17.

33. Ibid., 92-3.

34. Israel W. Charny, "Toward a Generic Definition of Genocide," in The Conceptual and Historical Dimensions of Genocide, ed. George Andreopolous (Philadelphia: University of Pennsylvania Press, 1994), 75; emphasis added.

35. Jacques Semelin, Purify and Destroy: The Political Uses of Massacre and Genocide (New York: Columbia University Press, 2007), 37-42, 332-42.

36. See Daniel J. Goldhagen, Hitler's Willing Executioners: Ordinary Germans and the Holocaust (New York: Knopf, 1996).

37. Helen Fein, Accounting for Genocide (New York: Free Press, 1979), 4. For a contrasting approach, see Henry C. Theriault, "Rethinking Dehumanization in Genocide," in The Armenian Genocide: Cultural and Ethical Legacies, ed. Richard G. Hovannisian (New Brunswick, NJ: Transaction, 2007), 27-40.

38. Norman Cohn, Warrant for Genocide: The Myth of the Jewish World-Conspiracy and the Protocols of the Elders of Zion, 3rd ed. (Chico, CA: Scholars Press, 1981), 12-13.

39. Ibid., 12-13.

40. Martin Shaw, War and Genocide (Cambridge: Polity Press, 2003); Shaw, What is Genocide? (Cambridge: Polity Press, 2007).

41. These arguments are elaborated in A. Dirk Moses, "Paranoia and Partisanship: Genocide Studies, Holocaust Historiography and the 'Apocalyptic Conjuncture," The Historical Journal 54, no. 2 (2011): 553-83. 
42. This is of course what Bloxham was arguing in his book, a point Bartov repeats when it suits his purposes.

43. See the autobiographical sketches in Pioneers of Genocide Studies: Confronting Mass Death in the Century of Genocide, ed. Samuel Totten and Steven L. Jacobs (Westport, CT: Greenwood Press, 2002).

44. Robert Melson, Revolution and Genocide: On the Origins of the Armenian Genocide and the Holocaust (Chicago: University of Chicago Press, 1992), xviii.

45. Robert Melson, "My Journey in the Study of Genocide," in Totten and Jacobs, Pioneers of Genocide Studies, 142; Robert Melson, "Nigerian Politics and the General Strike of 1964," in Protest and Power in Black Africa, ed. Robert A. Rotberg and Ali A. Mazrui (New York: Oxford University Press, 1970), 171-87. He analyzes the Biafra question in Robert Melson and Howard Wolpe, eds., Nigeria: Modernization and the Politics of Communalism (East Lansing: Michigan State University Press, 1971). Later, he would write about his Jewish family's survival during the Holocaust: Robert Melson, False Papers: Deception and Survival in the Holocaust (Urbana: University of Illinois Press, 2000). See also Robert Melson, "Return to Prague: The Presence of the Past," Midstream 56, no. 3 (Summer 2010): 20-24.

46. Fein, Accounting for Genocide; Helen Fein, Imperial Crime and Punishment: The Massacre at Jallianwala Bagh and British Judgment, 1919-1920 (Honolulu: University of Hawaii Press, 1977).

47. Jack Nusan Porter, Jewish Radicalism (New York: Grove Press, 1973); Porter, "Sociology and Genocide Studies," Footnotes: A Publication of the American Sociological Association 36, no. 5 (May-June 2008): http://www.asanet.org/footnotes/mayjun08/geno.html.

48. Irving Louis Horowitz, "Gauging Genocide: Social Science Dimensions and Dilemmas," in Totten and Jacobs, Pioneers of Genocide Studies, 256-57.

49. Israel W. Charny, "Narrative Biography," Prevent Genocide, http://preventgenocide.org/ education/events/charnyCV2000.htm (accessed 1 July 2011).

50. Daniel J. Goldhagen, “In Sudan, Say 'Never Again,' And Mean It,” Forward, 13 July 2011, http://forward.com/articles/139761.

51. See the brilliant discussion of Irving Horowitz, "Many Genocides, One Holocaust? The Limits of the Rights of States and the Obligations of Individuals," Modern Judaism 1, no. 1 (1981): 74-89.

52. See Helen Fein's rejection of Steven T. Katz's arguments (in The Holocaust in Historical Context [New York: Oxford University Press, 1994]) in her Genocide: A Sociological Perspective (London: Sage, 1993), 53. See, generally, Dan Stone, "The Historiography of Genocide: Beyond 'Uniqueness' and Ethnic Competition,” Rethinking History 8, no. 1 (2004): 127-42.

53. Melson, "My Journey in the Study of Genocide," 142.

54. This criticism could be made of Goldhagen's argument. See note 49 above. Cf. Mark Mazower, "Violence and the State in the Twentieth Century," American Historical Review 107, no. 4 (2002): 1158-78.

55. Raphael Lemkin, "Part I, Ch. II, Sec. II: The Nature of the Group Concerned," American Jewish Archives, Cincinnati, Collection 6, Box 7, Folder 7/2, 3.

56. For analyses of these debates, see A. Dirk Moses, "Genocide and Modernity," in Stone, The Historiography of Genocide, 156-93.

57. Aimé Césaire, Discourse on Colonialism, trans. Joan Pinkham (New York, 1972 [1955]).

58. A.G. Hopkins, "Comparing British and American Empires," Journal of Global History 2 (2007): 404.

59. Ibid., 403.

60. Ibid., 403-404.

61. Bartov, "Genocide and the Holocaust," 388. 